\title{
INTEGRATED COMPONENTS OF INTERCULTURAL COMPETENCE IN ENGLISH LANGUAGE TEACHING AT COLLEGE: CASE STUDY
}

\author{
Mohammad Hesan \\ mohammadhesan95@gmail.com \\ State University of Surabaya, Indonesia \\ Ahmad Munir \\ ahmadmunir@unesa.ac.id \\ State University of Surabaya, Indonesia \\ Slamet Setiawan \\ slamet.setiawan@unesa.ac.id \\ State University of Surabaya, Indonesia
}

\begin{abstract}
In this global world, foreign language teaching has been demanded to be intercultural teaching which means that cultural teaching should be integrated in language teaching as well as language competence, in English language teaching for instance. On the ground that the importance of foreign language teaching and learning is largely for purpose of international communication, and intercultural knowledge has crucial role in successful communication. Therefore, this paper reports on a qualitative case study which investigates two English teachers' practice of integrating intercultural competence in English language teaching at college level. Specifically, this paper provides analysis of intercultural components embedded in teachers' practice of intercultural integration in teaching English. The data were collected through observation, and unstructured observational notes were employed. The observational data were analysed following sub-processes, are familiarizing, reducing, identifying and classifying, interpreting, and presenting. The result indicates that both English teachers' understand the objective of English language teaching that teaching language is also teaching the culture as it is showed in their teaching process an intercultural integration, which includes some intercultural components such as attitudes, knowledge, and skills.
\end{abstract}

Keywords: Teachers' intercultural integration, intercultural components, English language teaching, college level.

\section{INTRODUCTION}

In foreign language teaching, if a teacher focuses the learning objectives on communication skills and language competence, the teaching practice will come closer to the acquisition of communicative competence (Sercu et al., 2005). On the contrary, if a teacher perceives that intercultural promotion gives a large implication in foreign language teaching and learning, the teaching practice "will be more more interculralise foreign language education that would enable the learners successful in international communication" (Sercu et al., 2005, p. 19). The integration of communicative competence and intercultural competence emerges concept of intercultural communicative competence (ICC).

Communicative competence refers to ability to perform the target language linguistically, socio-linguistically, and pragmatically in appropriate way (Atay, Kurt, Camlibe, Ersin, \& Kaslioglu, 2009). In this view, cultural integration is not acquired in 
language teaching in which the teacher is demanded to concern to the pupils' language skill as the objective. Meanwhile, intercultural competence is generally defined as ability to build effective communication with people from different groups by negotiating appropriate behavior to respect cultural differences (Bennett, 2015). The concept of intercultural competence is often attracted many scholars so that several models addressing to intercultural competence emerged. Byram in 1997, emphasized that cultural teaching should be integrated in language teaching as well as linguistic competence by comprising intercultural competence into attitudes, knowledge, skills (skill of interpreting and relating, and skill of discovery or interaction), and critical cultural awareness. Thereby, the way teacher perceives the objective of foreign language teaching will influence their teaching practice and pupils' achievement, in teaching English as foreign language for instance.

English status in the world indicates how English takes the crucial roles in multilingual countries, including Indonesia. For instance, English is brought into educational system as foreign language teaching with some purposes such as for study, business, international encounter, cultural exchange, even it gives a better chance to get a job. Bridging English into educational system as foreign language teaching also means bridging the culture of the native speaker toward the pupils to enable them successful in international communication. Intercultural communication is merely engaged between or among the communicators in which such a thing aims to build interpersonal relationship and to share one culture to another. Therefore, the communicators, in communication process, are heaps of time integrate their cultural communicative on their language ability. This matter provides an explanation that language and culture are correlated one another as language is the real reflection of culture. In accordance with Nguyen Lai (Ha, 2008), language is embedded in culture, and with its complexity, language influences culture.

However, English language teaching in Indonesia is still longer concerned to communicative competence, which focuses on the pupils' acquisition of the target language taught. It may not suit to the goal of pupils in learning English. Siregar and Henny (2013) found that the reason of pupils at Maranatha Christian University learning English is mostly addressed to communicate with native and non-native English speaker. In fact, successful communication in international contact is not largely influenced by the linguisctic competence of the target language, but also intercultural knowledge of the target culture. On the ground that pupils will face English native and non-native English speaker with diverse backgrounds. Thus, the English teachers are supposed to move from traditional notion of foreign language teaching, communicative teaching concern, to intercultural teaching as an integration for purpose of fostering pupils' intercultual communicative competence. Sercu, et al. (2005) suggested that cultural teaching is possibly embedded in foreign language teaching objectives for purpose of promoting pupils' familiarity with the culture of foreign language taught, and promoting the acquisition of open mind toward unfamiliar cultures.

Some extant studies have provided some investigations in dealing with intercultural competence in language teaching. Syahri (2010), in his study, compared communicative competence and intercultural communicative competence believed more promising toward pupils' achievement. This study attempts to promote the importance of developing pupils' intercultural communicative competence in English learning that they will be more ready to encounter in the global arena of which people with diverse cultural background use English as medium of international communication either for purpose of interaction or transaction. Kusumaningputri and Widodo conducted a classroom-based study which investigates "the use of digital photograph-mediated intercultural task to promote students' critical intercultural awareness in the tertiary ELT context" (2018, p. 49). This study only concerns to build pupils critical cultural awareness as part of intercultural component of intercultural competence. 


\section{Components of Intercultural Competence}

Tolosa et al, (2018), focus on school language teachers' understanding of intercultural teaching and their practice of intercultural teaching through foreign language lesson at New Zealand. Reid (2015) conducted a library study focused on developing several techniques to help English teachers developing the students' intercultural competence, but it did not provide evidence in term of teachers' perception and practice of intercultural teaching by using the techniques proposed.

Thereby, there is paucity to be filled through the current study by investigating the current demand of objectives in English language teaching, is to integrate intercultural competence as well as linguistic competence. Therefore, the current study focuses on an investigation about two teachers' practice of intercultural integration in English language teaching at college level. Then, it raises a formulated research question: what components of intercultural competence do the teachers integrate in English language teaching to encourage pupils bearing intercultural communicative competence? Thus, this study aims to identify and describe what components of intercultural competence integrated by the teachers in teaching English.

\section{METHOD}

The investigation raises a trend view of objective of foreign language teaching, English, which is addressing the pupils to have intercultural communicative competence by promoting the cultural teaching in English lesson. Therefore, this study uses qualitative approach and collective case study as research method. In which, collective case study is a term to address "multiple cases which are described and compared to provide insight into an issue" (Creswell, 2012). The case of this study refers to several individuals, English teachers, focused to their practice of the intercultural integration in English language teaching.

This study was set at college level of which there are two colleges chosen: the first is state college located in Madura and the second is private college located in Surabaya. The setting was specifically set at English class of speaking course for English department students in academic year 2018/2019. Moreover, speaking class was chosen because it is skill based course which concerns to oral communication skill which would enable pupils to have good competence in using the target language orally in communication process. The subjects of this study were two English teachers of speaking course: one is representative of a state college in Madura and another is representative of private college in Surabaya. Both teachers were chosen on the ground that they are aware of the importance of culture in foreign language teaching and learning so that the cultural aspects are attempted to be involved in teaching and learning process following the students' learning practices in the class. It meets the focus of this study which aims to investigate intecultural competence which is integrated in English language teaching to enable pupils successful in international commununication.

As an attempt to get data regarding intercultural components embedded in teachers' practice of intercultural integration, data were collected by using one technique, is observation. In this section, non-participant observation was employed, and it was done more than one month: on $8^{\text {th }}$ April to $21^{\text {st }}$ May, 2019. In detail, in the first setting (in Madura), observation was done five-time and in the second setting (in Surabaya) was done three-time. The former is longer on the ground that in some meetings, the teaching practices focused more on students communicative competence so that intercultural competence were not integrated. Observational data were collected by entering the class and observing the teaching and learning process from distance and taking notes.

After the data are collected, the further procedure is analyzing data following some steps: familiarizing, reducing, identifying and classifying, interpreting, and presenting. At first, the data were familiarized through comprehend reading and reduced to obtain the qualified one based on the research question. After reducing, the following step is identifying what components of intercultural competence integrated by teachers in teaching English. The 
process of identifying is correlated to Byram's developmental model of intercultural competence (1997), which consists of five components including attitudes, knowledge, skills (skill of interpreting and relating, and skill of discovery or interaction) and critical cultural awareness or political education. Furthermore, teachers' practice of intercultural integration in English language teaching is classified based on the five components that have been identified above. Finally, the data analysis was interpreted to draw a conclusion and represent the data descriptively. As previously stated, in this analysis, the data were correlated to Byram's developmental model of intercultural competence in 1997. Thus, the conclusion is presented descriptively about what intercultural components integrated by teachers in teaching English especially in teaching speaking course.

\section{RESULT}

In this section, after data were analyzed, the result are then presented and discussed in the following to answer the formulated research question in relation to intercultural components integrated by both English teachers in English language teaching. Thus, the results are described case by case in accordance with the subjects of this study, are English teachers, focused on their intercultural teaching correlated to Byram's developmental model of intercultural competence (1997).

\subsection{First case: intercultural components integrated by the first English teacher.}

The concept of intercultural competence is often attracted many scholars so that several models addressing to intercultural competence emerged. For instance, Byram in 1997, emphasized that cultural teaching should be integrated in language teaching as well as linguistic competence by comprising intercultural competence into attitudes, knowledge, skills (skill of interpreting and relating, and skill of discovery or interaction), and critical cultural awareness. However, based on the result of observation to the first teacher's teaching process, it was only found one component of five, is attitudes. The component is reflected by teacher's verbal and nonverbal communication while teaching process occurred.

\subsubsection{Attitudes}

In the first observation, the teacher began the meeting by uttering Salam. After all students had answered it together, she continued with asking their condition at that day. Then, they gave her a response by saying that more than half of them are fifty-fifty which indicated that they were both sorrowful and ecstatic at the same time. Before going to the main activity, the teacher teaches the students about politeness such as to give greeting when entering the class lately.

What the teacher did as mentioned above is part of intercultural teaching including attitude, as one of intercultural components. In this section, the teacher enables to have readiness to engage with intercultural communication by teaching them to familiarize with expressions of thanking and responses by practicing them in daily activity. Some scholars, including Byram (1997), view that attitudes are fundamental intercultural component, which is constituted by some indicators including curiosity, openness, respect, and tolerance (Bennett, 2015). Deardorff (2006) mentioned that attitude "has been referred to as the affective filter in other models". Lynch and Hanson (1998) emphasized that attitude takes fundamental role of other components of intercultural competence since they wrote, "After all the books have been read and the skills learned and practiced, the cross-cultural effectiveness of each of us will vary. And it will vary more by what we bring to the learning than by what we have learned" (p. 510). 


\section{Components of Intercultural Competence}

Furthermore, the teacher started the main activities by implementing a game, "Guess My Gestures". Students shouted happily of it. She directly asked them to make a group of four members consisted of students with the same initial letter of their name. For instance, students with the initial name started with $\mathrm{M}$ will be with other students having the same $\mathrm{M}$ letter and so on. After students gathered with their group forming a circular shape, she asked them to take a piece of blank paper tore up into 3 smaller pieces and instructed them to write a sentence for each piece arranged in not less than 3 words, yet not more than 5 words at all. When finished, pieces of paper were handed in and the game was begun. The teacher took one paper randomly and pointed one student, the representative of the group, to come forward and expressed a gesture to visualize the sentence in the paper she held and let another students to guess what she meant. The teacher gave the same opportunity for them to guess and got the score.

Through that kind of activity, the teacher consciously teaches the students not only to have good skill in verbal communication, but also non-verbal communication. The teacher explained the students about the importance of non-verbal communication such gesture, body movement, and eye contact in communication such as to gather the interlocutors' attention and especially to make interlocutor understand more the message intend to convey. In line, Argyle in 1983 (cited in Byram, 1997) mentioned that non-verbal communication has four functions: to communicate interpersonal attitudes and share emotions, to operate selfpresentation, to operate rituals, and to support verbal communication. Such a case, also enables students to have readiness in intercultural communication as one of objectives which constitutes attitudes in accordance with Byram (1997, p. 50).

Moreover, attitude, as an intercultural component, was also found in another observation. The teacher also enables the students to have good non-verbal communication the the students will be going to do an oration. Before students were given time to discuss more about their preparation, the lecturer provided them with some instructions and guidance about the activity. First thing first, the lecturer gave them insight of what oration was and how it was exhibited. She explained procedures in detail about it. Students were advised to use diction properly in terms of politeness, while showing exceptional non-verbal communication, such as gestures, body movement, body language and eye contact. Just being discussed verbally, however, did not let them grasp what the lecturer aimed at being understood, thus she gave them example through real gestures and activities of the orator. Then, it was so much helpful for them to understand.

Argyle as cited in Byram's book 1997, points out that "there is variation in non-verbal communication between cultures and that 'when people from two different cultures meet, there is infinite scope for misunderstanding and confusion"' (p. 13). He briefly correlate it with the ways of overcoming such problems. Furthermore, he suggests that language learning is a valuable but time-consuming approach to other cultures, as are modes of social skills learning which prepare people for contact with other cultures.

Since intercultural competence is linked to communicative competece as an integrated one, such combination is called as intercultural communicative competence. In accordance with Chen and Starosta (Zhou \& Griffiths, 2011), intercultural communicative competence is ability to communicate effectively and appropriately by negotiating meaning of intercultural components in intercultural setting. In their definition, intercultural communicative competence are constituted by three components, are "intercultural sensitivity (affective process), intercultural awareness (cognitive process), and intercultural adroitness (behavioural process), which basically refers to our verbal and non-verbal factors of communication mentioned above as a part of intercultural competence" (Zhou \& Griffiths, 2011, p. 114).

\subsection{Second case: intercultural components integrated by the second English teacher.}


In this case, the teacher's practice of intercultural integration in teaching English consciously emerged in which the teacher attempts to bridge the students toward cultural difference between local culture and the target culture of language the learn. The teacher intends to enable the students to know the social difference, to identify the culture values and events, and to have ability to interpret cultural values of events in perspective of their own culture and foreign culture. Thus, based on the result of observational data analysis of the second teacher's teaching process, it was found three components of intercultural competence. Those are attitudes, knowledge, and skills of interpreting and relating, as presented in the following:

\subsubsection{Attitudes}

In the first observation, the topic discussed was about beauty contest. At first, the teacher gave greeting to students and followed by introduction of the topic to be discussed, "beauty contest". In this section, technique used by the teacher to deliver the material was simple debate. Before discussing the topic deeper, the teacher gave brief introduction about the coming of contestants of miss world to Bali, Indonesia in 2013. The teacher told the students how that occasion emerged some protest by some Indonesian parties, Majlis Ulama Indonesia for instance.

In such a case, what teacher did includes intercultural component classified as attitudes. In which, the teacher shows the students intercultural awareness and how Indonesian people view the cultural difference between their own country and other country in perspective of their own culture. it means that not all foreign culture is viewed positively even negative attitudes are addressed to foreign culture regarded not suitable with the local culture. "Some recent studies consider attitudes to be foundational to the acquisition and development of intercultural competence" (Bennett, 2015, p. 219). Crucial attitudes necessary for intercultural competence include curiosity, openness, respect, and tolerance. Curiosity refers to desire to have insight about foreign culture; openness is described as self-avoidance to make judgment about other cultures; respect means valuing other as well as self; and tolerance means acceptance toward the diversity of one's self-identity and other's self-identity including cultural diversity (Bennett, 2015). Byram in 1997 formulated objectives in foreign language teaching which constitute attitudes of intercultural competence, which includes: desire to engage within the intercultural context, interest to know local culture and foreign culture in perspective of one's own country and other country, willingness to know the cultural values, practices, and products in one's own setting, readiness to engage with intercultural communication, and so on (p. 50).

\subsubsection{Knowledge}

The second component found in the second teacher's teaching process as taken through observational notes is knowledge. Byram defines knowledge as ability to acknowledge own social groups, products, practices, and social interaction in both sides: own country and interlocutor's country. Here, based on the observational data analysis, the teacher integrated intercultural knowledge by giving some questions relating to cultural aspects of the topic discussed. In such a thing, one of aspects which becomes main concern is about fashion of other such as physical appearance and intelligence. The teacher enabled the students to make comparison between the beauty contest in national level and international level. In international, there are miss world, miss international, miss universe, and so forth, while in national there are Miss Indonesia and Putri Muslimah, taken as examples. In this case, in accordance with Byram' developmental model of intercultural competence (1997), what the teacher did in his teaching process meets one of indicators of intercultural knowledge, is to 


\section{Components of Intercultural Competence}

enable students to know the social differences and principal markers of speaker and interlocutor.

Moreover, the teacher also tried to integrate local culture relating to beauty contest by mentioning one of the contests in region level, Cak dan Ning. The teacher stimulated the students to give their opinion about Cak dan Ning contest and enabled them to make comparison among those three different contests: local culture, national culture, and foreign culture of the target language they learn. Cak dan Ning in English is called as "Mr and Miss". It is kind of Javanese contest to choose $\mathrm{Mr}$ and Miss as representative from a region. The teacher did not give more explanation about Cak dan Ning competition because the students are from Java so they have been familiar on the contest.

In accordance with Bannett, when people from different background encounter, intercultural communication could not be neglected. Thereby, knowing own social identity (e.g culture) and others' social identity (e.g. "culture, language, \& contextual knowledge such as history, cultural artifacts, political system," etc.) are crucial areas of knowledge as intercultural component (2015, p. 218). In which, those influence the success of interaction in intercultural context which is able to be indicated by the effective information exchange and the established relationship (Byram, 1997). Therefore, in foreign language teaching such as English, intercultural knowledge must be integrated to students' learning to enable them successful in intercultural communication. Alptekin in specific context, English language teaching, argued that the conception of communicative competence needs to refine by concerning to world English (2002). In which, it engages local and international context as setting in language use by negotiating intercultural insight and knowledge of the individuals. Such a case results a concept of intercultural communication competence, especially in context of ELT.

Karabinar \& Guler (2013) who studied intercultural competence in perspective of language teachers, suggested that in context of foreign language education, integrating intercultural competence and communicative competence is a must. In fact, the importance of culture, in the real world of communication, has carried new demands in foreign language teaching. Thereby, addressing students to have intercultural knowledge is crucial thing in English language teaching and learning. For instance, in another observation, the teacher taught speaking course with the topic to be discussed is about "song". The topic was delivered though lecturing and discussion activity. In this activity, the teacher enables the students to know the national memory of one's own and interlocutor's country, and its relationship in perspective of communicators (Byram, 1997). It is reflected by the teacher's practice of intercultural integration. Based on the result of second observation, the teacher gave stimulating question related to the topic as brainstorming. For instance, the teacher asked the students about the lyric content of western song. Some students' answers were covered such as sexual content, nudity, drugs and violence. The teacher then explained that western song especially for the lyric tend to be sexual content which is not appropriate The teacher then tried to bridge the students to the history of Indonesian music in 1959, is Soekarno's leadership era of which rock and roll music has influenced Indonesian music.

\subsubsection{Skills of interpreting and relating}

Apart from intercultural attitudes and knowledge, another component was identified in the second observation of the second teacher's teaching process. The component is skills of interpreting and relating, defined as ability of analyzing data by concerning to the content of communication from one's own and others', verbal or non-verbal, (Bennett, 2015, p. 218), to "establish the potential relationships between them" (Byram, 1997, p. 33). The better skill individual has to communicate across cultural context, the more natural communication process he or she does. It means that skills, as intercultural component, determine the nature of communication process. Byram elaborated intercultural skills into two: skills of 
interpreting and relating, and skills of discovering and interacting (1997). In this section, the teacher enables pupils to have ability to identify and explain the origins of cultural document or event in ethnocentric perspectives, ability to bridge between misinterpretation of phenomena, and ability to identify the misinterpretation of an interaction and clarify based on terms of the cultural system.

Based on the result of observation, the teacher asked the students whether they have question or not relating to the kind of song before running to further discussion, but no one want to ask. Then, the teacher continued the teaching learning process by asking students their favorite song. Some titles of song were listed on the white board by the teacher based on the students' answer. Those are dusk till down, overdose, please me, shape of you, and love me harder. The teacher then asked the students to identify the kind of content included in the songs seen from the title whether the songs talked about sexual content, drugs or something else. The teacher explained that the title may present the content of the lyric. The titles of song were identified together of which dusk till down was identified as sexual content, overdose is drug or addicted, and other are identified as sexual content.

After identifying the kind of content of the song based on the title, the teacher then asked the students to browse in internet the lyric and analyze it which part of the lyric which reflects the kind of content have been identified before. For instance, which part of the lyric which describes sexual content, drugs, etc. As the result, the lyric analysis is suitable with what have been predicted by the students based on identifying the kind of content included the songs from those titles.

\section{CONCLUSION}

In educational framework, when pupils learn English as foreign language, they will be recognized to the culture of native language user, so that the pupils will try to understand the target culture as well as their own culture associated to the foreign language they learn (Sercu et al., 2005). It is clear that there is a shift in term of the view of foreign language teaching objective in general, of which, traditionally, foreign language teacher focused on language competence of the target language that refers to native speaker's knowledge of syntactic, lexical, morphological, and phonological features of the language. However, in contemporary, learners are not only expected to perform the target language accurately, but also to use the language in the real life in the target language setting, reflecting the native speakers' culture (Alptekin, 2002). Thus, foreign language teaching will be enculturation by integrating language and culture to develop learners' communicative competence. From the result of this study, it could be concluded that both English teachers are full of potentially awareness toward the current demand of English language teaching of which the teachers not only concern to the acquisition of linguistic competence but also involve intercultural competence as an integration to enable students to have intercultural communicative competence. such integrations are provided in teachers' teaching process in speaking class, as proven by the intercultural components inserted in their English language teaching, especially in speaking class.

\section{REFERENCES}

Alptekin, C. (2002). Towards InterculturalCommunicative Competence in ELT. ELT Journal, LVI(1), 57-64.

Atay, D., Kurt, G., Camlibe, Z., Ersin, P., \& Kaslioglu, O. (2009). The Role of Intercultural Competence in Foreign Language Teaching. Inonu University Journal of the Faculty of Education, X(3), 123-135. 


\section{Components of Intercultural Competence}

Bennett, J. M. (Ed.). (2015). The SAGE Encyclopedia of Intercultural Competence. Boston: SAGE Publications.

Byram, M. (1997). Teaching and Assessing Intercultural Communicative Competence Multilingual Matters. Clevedon: Multilingual Matters.

Creswell, J. W. (2012). Educational Research: Planning, Conducting, and Evaluating Quantitative and Qualitative Research. Boston: Pearson.

Deardorff, D. K. (2006). Identification and Assessment of Intercultural Competence as a Student Outcome of Internationalization. Journal of Studies in International Education, 241-266.

Ha, L. P. (2008). Teaching English as an International Language: Identity, Resistance, and Negotiation. United Kingdom: Mulitilingual Matters Ltd.

Karabinar, S., \& Guler, C. Y. (2013). A Review of Intercultural Competence from Language Teacher's Perspetive. Procedia - Social and Behavioral Sciences, LXX, 1316-1328.

Kusumaningputri, R., \& Widodo, H. P. (2018). Promoting Indonesian university students' critical intercultural awareness in tertiary EAL classrooms: The use of digital photograph-mediated intercultural tasks. System, LXXII, 49-61.

Lynch, E. W., \& Hanson, M. J. (1998). Developing cross-cultural competence: A guide for working with children and families. Pacific Grove, CA: Brookes/Cole.

Reid, E. (2015). Techniques Developing Intercultural Communicative Competences in English Language Lesson. Procedia - Social and Behavioral Sciences(186), 939-943.

Sercu, L., Bandura, E., Castro, P., Davcheva, L., Laskaridou, C., Lundgren, U., et al. (2005). Foreign Language Teachers and Intercultural Competence: An International Investigation. United Kingdom: Multilingual Matters Ltd.

Siregar, F. L., \& Henni. (2013). Needs Analysis of English Intercultural Competence Features Believed to be Important by EFL Students at Maranatha Cristian University. Zenit, 211218.

Syahri, I. (2010). Explicit Comparisons in Developing Intercultural Competence. Leksika, IV (2), 48-55.

Tolosa, C., Biebricher, C., East, M., \& Howard, J. (2018). Intercultural Language Teaching as a Catalyst for Teacher Inquiry. Teaching and Teacher Education(70), 227-235.

Zhou, C., \& Griffiths, C. (2011). Interculturl Communicative Competence. English Language and Literature Studies, I(2). 